\title{
Zebra mussels mediate benthic-pelagic coupling by biodeposition and changing detrital stoichiometry
}

\author{
RENÉ GERGS, KARSTEN RINKE AND KARL-OTTO ROTHHAUPT \\ Limnological Institute, University of Konstanz, Konstanz, Germany
}

\begin{abstract}
SUMMARY
1. The zebra mussel (Dreissena polymorpha) is one of the most successful invasive species; it has colonised many aquatic systems in Europe and North America with strong impacts on various ecosystem processes. The effect of $D$. polymorpha filtration on pelagic seston concentrations has been quantified in several studies, but the magnitude and stoichiometry of the transfer of sestonic biomass into benthic detritus by $D$. polymorpha and the accompanying enrichment of the benthic habitat is still under-investigated.

2. We studied biodeposition by zebra mussels in two series of laboratory experiments with the food algae Cryptomonas erosa and Scenedesmus obliquus. We also measured the yearround biodeposition rate under natural conditions in the oligotrophic Lake Constance.

3. In all experiments, zebra mussel biodeposition was linearly related to seston concentration. In the field, the relationship changed with a seasonal shift in algal composition and lower biodeposition rates during the spring algal bloom.

4. For both algal species in laboratory experiments, biodeposited material was depleted in phosphorous at an algal concentration $\leq 0.6 \mathrm{mg}$ ash-free dry mass $\mathrm{L}^{-1}$, but not at higher concentrations. This effect was not observed in the field, probably because of high variation in $\mathrm{C}: \mathrm{N}: \mathrm{P}$ stoichiometry.

5. By mediating the transfer of pelagic resources into the benthos zebra mussels provide a sufficient amount of detritus for benthic invertebrates, especially during summer. Thus, material biodeposited by the mussels might increase benthic secondary production from pelagic resources, and zebra mussels are important mediators of this flux of organic matter from the pelagic zone into the benthos.
\end{abstract}

Keywords: Dreissena polymorpha, food web, invasive species, organic matter, pseudofaeces

\section{Introduction}

The zebra mussel Dreissena polymorpha (PALLAS) plays an important role in altering the structure of aquatic ecosystems because the species usually develops large densities in invaded systems. Their filtration activity reduces the overall concentration of phytoplankton and depends on seston concentration; the rate is constant and maximal at food concentrations greater than $2 \mathrm{mg} \mathrm{C} \mathrm{L}^{-1}$ and declines exponentially at higher food concentrations (Walz, 1978a; Sprung \& Rose, 1988). When food concentration is sufficiently high, not all filtered material is ingested and agglomerated aggregates are rejected. These pseudofaeces consist of undigested algae and detritus bound in mucus and are periodically expelled by the inhalant siphon of the mussel (Stanczykowska, Lawacz \& Mattice, 1975). Pseudofaeces are produced at food concentrations above $0.2 \mathrm{mg} \mathrm{C} \mathrm{L}^{-1}$, and their production increases rapidly with an increasing food supply (Walz, 1978a).

The removal of algal cells and other seston components from the open water by $D$. polymorpha is an important mechanism in benthic-pelagic coupling

Correspondence: René Gergs, Limnological Institute, University of Konstanz, D-78467 Konstanz, Germany.

E-mail: rene.gergs@uni-konstanz.de 
(e.g. Boegman et al., 2008), whereas the biodeposition by $D$. polymorpha constitutes a mechanism that potentially supports benthic food webs. The flux of organic matter from the pelagic into the benthic zone is greatly increased by the continuous conversion of seston into faeces and pseudofaeces by $D$. polymorpha. This material is considered to support a biodeposition-based food web (Stewart \& Haynes, 1994; Mitchell et al., 1996) and affects the structure of benthic communities. The abundance of many benthic taxa, especially amphipods and chironomids, increases following the arrival of zebra mussels (Stewart \& Haynes, 1994; Stewart, Miner \& Lowe, 1998; Mörtl \& Rothhaupt, 2003). This is attributable to the high structural complexity of mussel shells, the accumulation of pelagic resources, and the increase in organic matter in the benthos (Stanczykowska et al., 1976; Klerks, Fraleigh \& Lawniczak, 1996; Silver Botts, Patterson \& Schloesser, 1996; Gergs \& Rothhaupt, 2008a). The organic matter is an additional food source for benthic invertebrates (Izvekova \& LvovaKatchanova, 1972; González \& Burkart, 2004; Gergs \& Rothhaupt, 2008b). From these observations, we conclude that $D$. polymorpha is a prominent mediator of benthic-pelagic coupling with consequences for both the pelagic and the benthic community. Moreover, we would expect the invasion of $D$. polymorpha into previously un-colonised habitats to induce a major change in the interaction between benthic and pelagic communities.

Dreissena polymorpha is highly selective in the food it ingests, and the selection is mostly dependent on particle size; the highest preference is for particles between 7 and $50 \mu \mathrm{m}$ (Ten Winkel \& Davids, 1982; Sprung \& Rose, 1988; Naddafi, Pettersson \& Eklöv, 2007). As a consequence, cryptophytes and small diatoms are ingested at high rates, whereas most large chlorophytes, cyanobacteria and pennate diatoms are rejected as pseudofaeces (Ten Winkel \& Davids, 1982; Holland, 1993; Bastviken, Caraco \& Cole, 1998; Naddafi et al., 2007). Less evidence is available about whether filtration selectivity is affected by food quality characteristics other than cell size (Ten Winkel \& Davids, 1982; Vanderploeg et al., 2001). Quality of ingested small algae can vary in terms of biochemical composition. Thus, cryptomonads are rich in polyunsaturated fatty acids, whereas green algae such as Scenedesmus obliquus (TURBIN) are poor in these substances (Wacker \&
Von Elert, 2004). These fatty acids can control growth and reproduction of zebra mussels (Wacker \& Von Elert, 2002, 2003).

The effect of biodeposition by $D$. polymorpha on the species composition and biomass of benthic communities has been intensively studied, but little is known about the year-round availability and quality (e.g. the stoichiometry) of this food source. Whereas biodeposition rate is linearly correlated to the seston concentration (Reeders \& Bij De Vaate, 1992; Klerks et al., 1996; Roditi, Strayer \& Findlay, 1997), pseudofaeces production appears to be restricted to high seston concentrations. At low seston concentrations, ingestion rate is not saturated and the deposited material consists mainly of faeces (MacIsaac \& Rocha, 1995; Roditi et al., 1997). Furthermore, elemental components of food can be assimilated with different efficiencies. For example, consumers limited by phosphorous, the most frequently limiting factor in oligotrophic freshwater systems (Lampert \& Sommer, 1999), are able to assimilate this limiting element with a higher efficiency than carbon (Rothhaupt, 1995; Sterner \& Elser, 2002).

In this study, we focused on the transfer magnitude of seston from the pelagic compartment into benthic detritus mediated by $D$. polymorpha. Since ingestion of algae by $D$. polymorpha is mainly driven by particle size, we hypothesised that biodeposition rate would not depend on the quality of the algal food and would also be mainly driven by food particle size under field conditions. Because at low food concentrations the biodeposited material consists entirely of faces, while with increasing seston concentration the relative importance of pseudofaces increases, we predicted an interaction between seston concentration and $\mathrm{C}: \mathrm{N}: \mathrm{P}$ stoichiometry. Accordingly, we hypothesised that biodeposited material would be depleted in phosphorous at low seston levels. To investigate these two hypotheses, we conducted laboratory experiments with a high and a low quality algal species (a cryptomonad and a green alga, respectively) at concentrations around the threshold of pseudofaeces production. We also investigated the year-round biodeposition rate of zebra mussels under natural conditions in the oligotrophic Lake Constance. Our results could also help to elucidate the importance of zebra mussels in benthic-pelagic coupling within oligotrophic aquatic systems since most studies performed to date have been in more eutrophic systems. 


\section{Methods}

\section{Collection and maintenance of zebra mussels}

Zebra mussels (D. polymorpha) for the field and laboratory experiments were obtained from the littoral zone of Lake Constance. D. polymorpha colonised the Rhine in the 1850s, but did not invade Lake Constance, through which the river flows near its southern end, until the 1960s (Siessegger, 1969). At the time of the introduction of this invasive species to the lake, intensive eutrophication began and continued until the late 1970s; since then, the lake has been subjected to strong re-oligotrophication. Today, Lake Constance is a pre-alpine lake with a relatively low seston concentration (Internationale Gewässerschutzkommission Für Den Bodensee, 2004).

Collected mussels were pre-sorted for the required size class (see below) and kept in a $15^{\circ} \mathrm{C}$ climate chamber with a light cycle of $12 \mathrm{~h}: 12 \mathrm{~h}$ (day : night). To minimise culturing effects, mussels were replaced by freshly collected mussels monthly. Mussels were cultured in a tank (approximately $90 \mathrm{~L}$ ) in a flowthrough system $\left(0.5 \mathrm{~L} \mathrm{~min}^{-1}\right)$ with filtered water $(30 \mu \mathrm{m})$ from Lake Constance. Stones from the lake were provided for mussel attachment. The mussels were fed ad libitum on the green alga Scenedesmus obliquus (SAG 276-3a, Sammlung von Algenkulturen Göttingen, Germany). The algae were grown in batch cultures in Cyano medium (Jüttner, Leonhardt \& Möhren, 1983).

\section{Laboratory experiments}

In the laboratory, we estimated $D$. polymorpha biodeposition rates when fed on the green alga Scenedesmus obliquus and when fed on the algal flagellate Cryptomonas erosa EHRENB. (Max-Planck Institute for Limnology, Plön, Germany), each at five different concentrations. S. obliquus was grown in Cyano medium (Jüttner et al., 1983), and C. erosa was grown in modified Woods Hole (WC) medium containing vitamins (Guillard, 1975). Both algal species were cultured semi-continuously at $20^{\circ} \mathrm{C}$ with an illumination of $120 \mu \mathrm{mol} \mathrm{m} \mathrm{m}^{-2} \mathrm{~s}^{-1}$ in sterile, aerated $5-\mathrm{L}$ vessels. Part $(25 \%)$ of the culture was harvested each day and replaced with freshly prepared medium, resulting in a dilution rate of
0.28 day $^{-1}$. Both algal species were harvested by centrifugation ( $S$. obliquus: $1890 \mathrm{~g}, 15 \mathrm{~min}$; C. erosa: $1180 \mathrm{~g}, 6 \mathrm{~min}$ ), and cells were resuspended in fresh medium. A defined carbon concentration was achieved by adjusting the resuspended cells to an optical density of 0.8 (photometric light extinction: $S$. obliquus, $480 \mathrm{~nm}$; C. erosa, $800 \mathrm{~nm}$ ). The final concentration of $S$. obliquus and C. erosa was 0.25 and $0.32 \mathrm{mg} \mathrm{C} \mathrm{mL}^{-1}$ respectively.

To estimate biodeposition rates, a flow-through system was used to keep the algal concentration constant. Lake water was filtered $(0.45 \mu \mathrm{m})$, aerated and kept at $16{ }^{\circ} \mathrm{C}$. The flow-through rate of this pretreated lake water was adjusted to $200 \mathrm{~mL} \mathrm{~min}^{-1}$. A calculated volume of prepared algal suspension was added continuously by a flexible-tube pump (Gilson, MiniPlus3; Villiers Le Bel, France). The experimental basin was $34 \times 40 \times 7.5 \mathrm{~cm}$ (width $\times$ depth $\times$ height), with a water level of $6 \mathrm{~cm}$, resulting in a water volume of $8 \mathrm{~L}$. To minimise sedimentation of the algae, the water in the basin was gently aerated.

In both sets of laboratory experiments, 15 living mussels (14-16 mm in length) were glued (UHU plus, 2-component epoxy resin glue; UHU, Bühl, Germany) to an unglazed tile $(4.7 \times 4.7 \mathrm{~cm})$, and their biodeposited material was estimated. A bare tile served as control. Each tile was placed in a mini-container $(5 \times 5 \times 2.5 \mathrm{~cm})$ and the containers with and without attached mussels were randomly placed in two rows within the basin. The experiments with $S$. obliquus at five concentrations ranging from 0.2 to $2.0 \mathrm{mg}$ ashfree dry mass (AFDM) $\mathrm{L}^{-1}$ ran consecutively from July to September 2005. The concentration of algae in the inflow was determined at the end of each experiment. The treatment with attached mussels was replicated six times; the control treatment and the estimation of algal concentration were replicated three times. The experiments with $C$. erosa at five concentrations ranging from 0.3 to $1.3 \mathrm{mg} A F D M \mathrm{~L}^{-1}$ ran consecutively from March to April 2006. The treatment with attached mussels, the control treatment and the estimation of the algal concentration were replicated six times. Each experiment lasted 3 days. At the end of each experiment, the material deposited in the containers was transferred to a beaker, and pure water was added to $100 \mathrm{~mL}$. Subsequently, analyses of the measured parameters (see below) were performed. 


\section{Field experiments}

Biodeposited material was collected in Lake Constance using modified sediment traps. Each sediment trap consisted of a tube of grey PVC $(50 \mathrm{~cm}$ length; $\varnothing$ $10 \mathrm{~cm})$ with a funnel and a PET flask $(200 \mathrm{~mL})$ fixed at the lower end of the tube to collect the settling sediment. At the upper end of the sediment trap, a clamp for two tiles $(4.7 \times 4.7 \mathrm{~cm})$ was fixed vertically. This clamp held the tiles in the centre above the opening of the sediment trap, ensuring that the faeces and pseudofaeces of the zebra mussels were collected in the trap. Fifteen living mussels (14-16 $\mathrm{mm}$ in length) were glued on each tile. Bare tiles served as a control. Traps were exposed for 7 days each month from August 2005 to September 2006 and additionally during the spring bloom from March to May 2007.

Five traps with attached mussels and five with bare tiles were exposed to the pelagial of Lake Constance on a pontoon at a depth of $2 \mathrm{~m}$. At the end of the exposure, the material in each funnel and PET flask was collected and filtered through a $200 \mu \mathrm{m}$ net to exclude zooplankton. Pure water was then added to a defined volume. Subsequently, analyses of the measured parameters (see below) were performed. At the beginning and the end of each exposure, seston at a depth of $2 \mathrm{~m}$ was sampled with a horizontal water sampler. Seston data from the beginning and end of each exposure period were pooled.

\section{Measured parameters}

The lengths of the zebra mussel shells were measured with a digital sliding calliper (Preisser; Digi-Met, Gammertingen, Germany) to the nearest $0.01 \mathrm{~mm}$.

The AFDM of each sample from the field and from the laboratory experiments was determined as follows. An aliquot of each sample was filtered on pre-combusted glass-fibre filter (Schleicher \& Schuell; GF/6; Ø $25 \mathrm{~mm}$, Dassel, Germany) and dried at $105^{\circ} \mathrm{C}$ for $24 \mathrm{~h}$. The filter was weighed (dry mass), combusted at $550^{\circ} \mathrm{C}$ for $8 \mathrm{~h}$, and then weighed again (ash content). The AFDM was calculated as the difference of the dry mass and the ash content. In both field and laboratory experiments, the biodeposition rate per zebra mussel and day was calculated as the difference in AFDM between the samples from attached mussels and the corresponding control.
To assess the nutrient content in samples from all experiments, we estimated the organic carbon, nitrogen and phosphorus stoichiometries of the deposited material. Aliquots of the samples were filtered on pre-combusted glass-fibre filters (Whatman GF/F; $\varnothing$ $25 \mathrm{~mm}$, Kent, U.K.). The samples were dried at $55^{\circ} \mathrm{C}$, and then particulate organic carbon and particulate organic nitrogen was analysed with an NCS-2500 analyser (Carlo Erba Instruments, Milano, Italy). To determine particulate phosphorus, aliquots of the samples were filtered through acid-rinsed polysulfone membrane filters (HT-200, Pall; $\varnothing$ $45 \mathrm{~mm}$, Ann Arbor, MI, U.S.A.). The samples were digested with $10 \%$ potassium peroxodisulfate and $1.5 \%$ sodium hydroxide at $121{ }^{\circ} \mathrm{C}$ for $60 \mathrm{~min}$, and soluble reactive phosphorus was determined using the molybdate-ascorbic acid method (Greenberg, Trussel \& Clesceri, 1985).

\section{Statistical analyses}

All statistical analyses were done using the statistical software package $\mathrm{R}$ ( $\mathrm{R}$ Development Core Team, 2006).

The dependence of biodeposition rate on seston concentration in both field and laboratory experiments was calculated by regression analyses. The data from laboratory experiments for each algal species were analysed separately. Differences between the regressions for laboratory data were analysed with ANCOVA. For the field data, a number of multiple linear models were calculated and compared using the Akaike Information Criterion (AIC). Based on maximum-likelihood estimates and the number of model parameters, the AIC provides a measure for selecting among competing models of a given data set. The model having the lowest AIC is chosen as the best model because it provides the best compromise between predictive power and model complexity (see Johnson \& Omland, 2004). Seasonal differences in biodeposition rate were detected using a one-way ANOVA with a subsequent Tukey HSD post-hoc test. The sampling dates can be denoted as independent, because factors that might influence zebra mussel biodeposition rate, seston concentration and phytoplankton community composition can change greatly within this time scale (Gaedke, 1998).

To determine stoichiometry, molar C : N, C : P and $\mathrm{N}: \mathrm{P}$ ratios were considered as dependent variables. 
Each field and laboratory experiment was analysed separately. Differences in stoichiometry between seston, control and biodeposited material were analysed with ANCOVA and a subsequent Tukey HSD post-hoc test. All stoichiometry data were $1 /(x)$ transformed, and homogeneity of variances was checked with the F-test. For the field data, the homogeneity of variances was not necessary because large, balanced experiments do not cause problems for the interpretation of an analysis with heterogeneous variances (Underwood, 2006).

\section{Results}

\section{Laboratory experiments}

We found significant linear, positive relationships between zebra mussel biodeposition rate and algal concentration in laboratory experiments with S. obliquus and C. erosa (Fig. 1; Table 1). Overall, biodeposition rates were not significantly different between the algal species (ANCOVA, $F=0.98, P=0.33$ ). However, biodeposition rate increased more steeply with increasing algal concentration when the mussels were fed $C$. erosa than $S$. obliquus (ANCOvA, algal species $\times$ seston concentration, $F=8.53, P=0.006$ ). At low algal concentrations, the amount of biodeposited material was similar in the two sets of experiments.

In the experiments with both algal species, posthoc tests revealed that $\mathrm{C}: \mathrm{P}$ and $\mathrm{C}: \mathrm{N}$ ratios of the biodeposited material differed from those of the

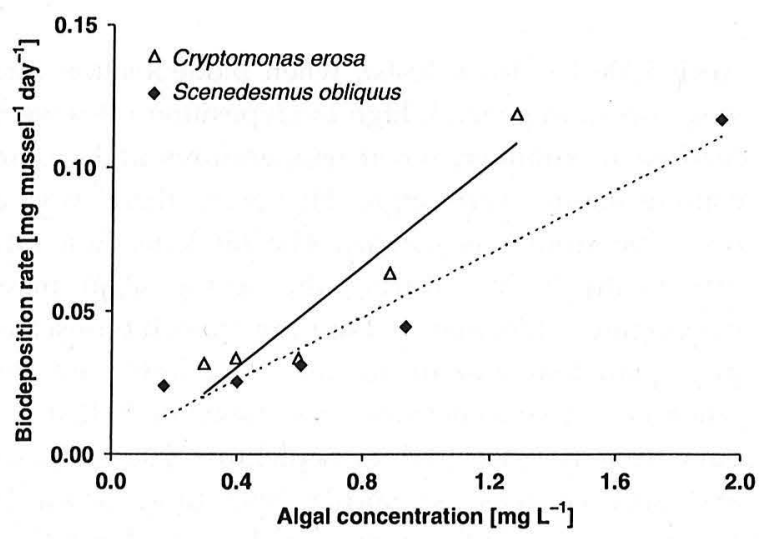

Fig. 1 Biodeposition rates in laboratory experiments with different algal concentrations. The algal mass unit is $\mathrm{mg}$ ash-free dry mass. Lines represent linear regressions for both algal species; for statistics see Table 1.
Table 1 Linear regressions between the ambient seston concentration and the biodeposition rate of Dreissena polymorpha in the laboratory and in the field

\begin{tabular}{lllll}
\hline & Intercept \pm SE & Slope \pm SE & $R^{2}$ & $P$-value* \\
\hline Laboratory & & & \\
Crypromonas & erosa & & & \\
AFDM $-0.005 \pm 0.013$ & $0.089 \pm 0.017$ & 0.90 & 0.013 \\
Carbon $-0.002 \pm 0.004$ & $0.034 \pm 0.005$ & 0.95 & 0.005 \\
Scenedesmus obliquus & & & \\
AFDM $\quad 0.004 \pm 0.007$ & $0.055 \pm 0.007$ & 0.95 & 0.005 \\
Carbon $\quad 0.004 \pm 0.006$ & $0.021 \pm 0.006$ & 0.83 & 0.032 \\
Field & & & & \\
Summer to winter & & & \\
AFDM $-0.026 \pm 0.026$ & $0.165 \pm 0.034$ & 0.73 & 0.001 \\
Carbon $-0.030 \pm 0.027$ & $0.130 \pm 0.035$ & 0.61 & 0.005 \\
Spring bloom & & & \\
AFDM -0.007 \pm 0.011 & $0.050 \pm 0.012$ & 0.81 & 0.015 \\
Carbon $-0.006 \pm 0.008$ & $0.320 \pm 0.008$ & 0.80 & 0.016 \\
\hline
\end{tabular}

*A significant regression. Note that the table provides regressions for the ash-free dry mass (AFDM) and carbon content of the biodeposited material dependent on the seston concentration.

seston and the controls, which were quite similar to each other (see Table 2). With either alga, when seston concentrations were low the $\mathrm{C}: \mathrm{P}$ ratio of biodeposited material was markedly higher than that of the control and of seston. At higher seston concentrations, however, this effect disappeared. This pattern was demonstrated by a significant compartment $x$ seston interaction term (compartments: biodeposited material, seston, control; ANCovA: C. erosa, $P=0.011$; $S$. obliquus, $P=0.009$; Table 2; Fig. 2 ). For both algal foods, the shift from higher $\mathrm{C}: \mathrm{P}$ ratios in the biodeposited material compared to that of control and seston to similar $\mathrm{C}: \mathrm{P}$ ratios consistently took place at a seston concentration of 0.6$0.9 \mathrm{mg} \mathrm{AFDM} \mathrm{L} \mathrm{L}^{-1}$. The same phenomenon was found for the N : P ratio in the experiments with $S$. obliquus (shown by a significant compartment $\times$ seston interaction term for the $\mathrm{N}: \mathrm{P}$ ratio: ANCOVA, $P=0.595$; Fig. 2). In the experiments with C. erosa, the $\mathrm{N}: \mathrm{P}$ ratio did not differ in the different compartments (ANCOVA, $P=0.099$ ). With either alga, the $C: N$ ratios of the biodeposited material and the seston differed, but that of the control did not differ from the other compartments (ANCOVA, C. erosa: $P=0.013$, S. obliquus: $P<0.001$; Table 2; Fig. 2). However, there was no significant compartment $\times$ seston interaction (ANCOVA: C. erosa, $P=0.153$; $S$. obliquus, $P=0.566)$. 
Table 2 Comparison of the $\mathrm{C}: \mathrm{N}: \mathrm{P}$ stoichiometry of Dreissena polymorpha biodeposited material, the control and the seston. The results were analysed by ANCOVA with the seston concentration as the covariate

\begin{tabular}{|c|c|c|c|c|c|c|c|}
\hline \multirow[b]{2}{*}{ Variable } & \multirow[b]{2}{*}{ Factor } & \multirow[b]{2}{*}{$F$-value } & \multirow[b]{2}{*}{ d.f. } & \multirow[b]{2}{*}{$P$-value } & \multicolumn{3}{|l|}{ Compartment } \\
\hline & & & & & $\begin{array}{l}\text { Biodeposited } \\
\text { material }\end{array}$ & Control & Seston \\
\hline \multicolumn{8}{|c|}{ Cryptomomas erosa } \\
\hline \multirow{3}{*}{$C: N$} & Seston & 14.92 & 1 & $<0.001^{*}$ & A & $\mathrm{AB}$ & B \\
\hline & Compartment & 4.56 & 2 & $0.013^{*}$ & & & \\
\hline & Compartment $\times$ seston & 1.92 & 2 & 0.153 & & & \\
\hline \multirow[t]{3}{*}{$C: P$} & Seston & 5.53 & 1 & $0.021^{*}$ & A & B & B \\
\hline & Compartment & 13.95 & 2 & $<0.001^{*}$ & & & \\
\hline & Compartment $\times$ seston & 4.78 & 2 & $0.011^{*}$ & & & \\
\hline \multirow[t]{3}{*}{$N: P$} & Seston & 2.33 & 1 & 0.131 & A & A & A \\
\hline & Compartment & 2.38 & 2 & 0.099 & & & \\
\hline & Compartment $\times$ seston & 0.52 & 2 & 0.595 & & & \\
\hline \multicolumn{8}{|c|}{ Scenedesmus obliquus } \\
\hline \multirow[t]{3}{*}{$C: N$} & Seston & 101.7 & 1 & $<0.001^{*}$ & A & $\mathrm{AB}$ & B \\
\hline & Compartment & 9.48 & 2 & $<0.001^{*}$ & & & \\
\hline & Compartment $\times$ seston & 0.57 & 2 & 0.566 & & & \\
\hline \multirow{3}{*}{$C: P$} & Seston & 41.88 & 1 & $<0.001^{*}$ & A & B & C \\
\hline & Compartment & 103.5 & 2 & $<0.001^{*}$ & & & \\
\hline & Compartment $\times$ seston & 5.13 & 2 & $0.009^{*}$ & & & \\
\hline \multirow[t]{3}{*}{$N: P$} & Seston & 2.23 & 1 & 0.141 & A & B & B \\
\hline & Compartment & 31.19 & 2 & $<0.001^{*}$ & & & \\
\hline & Compartment $\times$ seston & 4.55 & 2 & $0.014^{*}$ & & & \\
\hline \multicolumn{8}{|c|}{ Field experiment } \\
\hline \multirow[t]{3}{*}{$C: N$} & Seston & 1.46 & 1 & 0.228 & A & A & B \\
\hline & Compartment & 169.1 & 2 & $<0.001^{*}$ & & & \\
\hline & Compartment $\times$ seston & 4.74 & 2 & $0.009^{*}$ & & & \\
\hline \multirow[t]{3}{*}{$C: P$} & Seston & 3.20 & 1 & 0.075 & A & A & A \\
\hline & Compartment & 0.94 & 2 & 0.392 & & & \\
\hline & Compartment $\times$ seston & 16.22 & 2 & $<0.001^{*}$ & & & \\
\hline \multirow[t]{3}{*}{$N: P$} & Seston & 7.99 & 1 & $0.005^{*}$ & A & A & B \\
\hline & Compartment & 86.79 & 2 & $<0.001^{*}$ & & & \\
\hline & Compartment $\times$ seston & 7.68 & 2 & $<0.001^{*}$ & & & \\
\hline
\end{tabular}

*A significant ANCOVA result, and capital letters indicate homogenous subgroups detected by the subsequent Tukey-HSD post-hoc tests.

\section{Field experiments}

Sedimentation in the presence of zebra mussels was generally twice as high as in the control on all field sampling occasions, indicating that $D$. polymorpha markedly enhances the flux of organic matter from the pelagic to the benthic zone. In August 2005, for example, the deposited biomass in the presence of zebra mussels was approximately $40 \mathrm{mg}$ per trap compared to approximately $20 \mathrm{mg}$ per trap in the control (Fig. 3; $t$-test, $P=0.002$ ).

The biodeposition rate of zebra mussels varied seasonally (ANOVA, $P<0.001$; Fig. 4) and was higher in August-October 2005 and July-September 2006 than in December 2005, and January, March, and
April 2006 (post-hoc tests), when biodeposition rate was lowest. In general, high biodeposition rates were reached in summer, when temperatures and seston concentrations were high. However, there was a deviation from this pattern. The biodeposition rate was relatively low during the spring algal mass development (defined as the time from the onset of phytoplankton growth to the clear-water phase), when seston concentration was maximal. When the data from August 2005 to September 2006 (Fig. 4), and data collected in spring 2007 (not shown in Fig. 4) were pooled, we found only a weak relationship between biodeposition rate and seston concentration (Table 3, model 1.1). We hypothesised that either lower water temperature or a different algal 

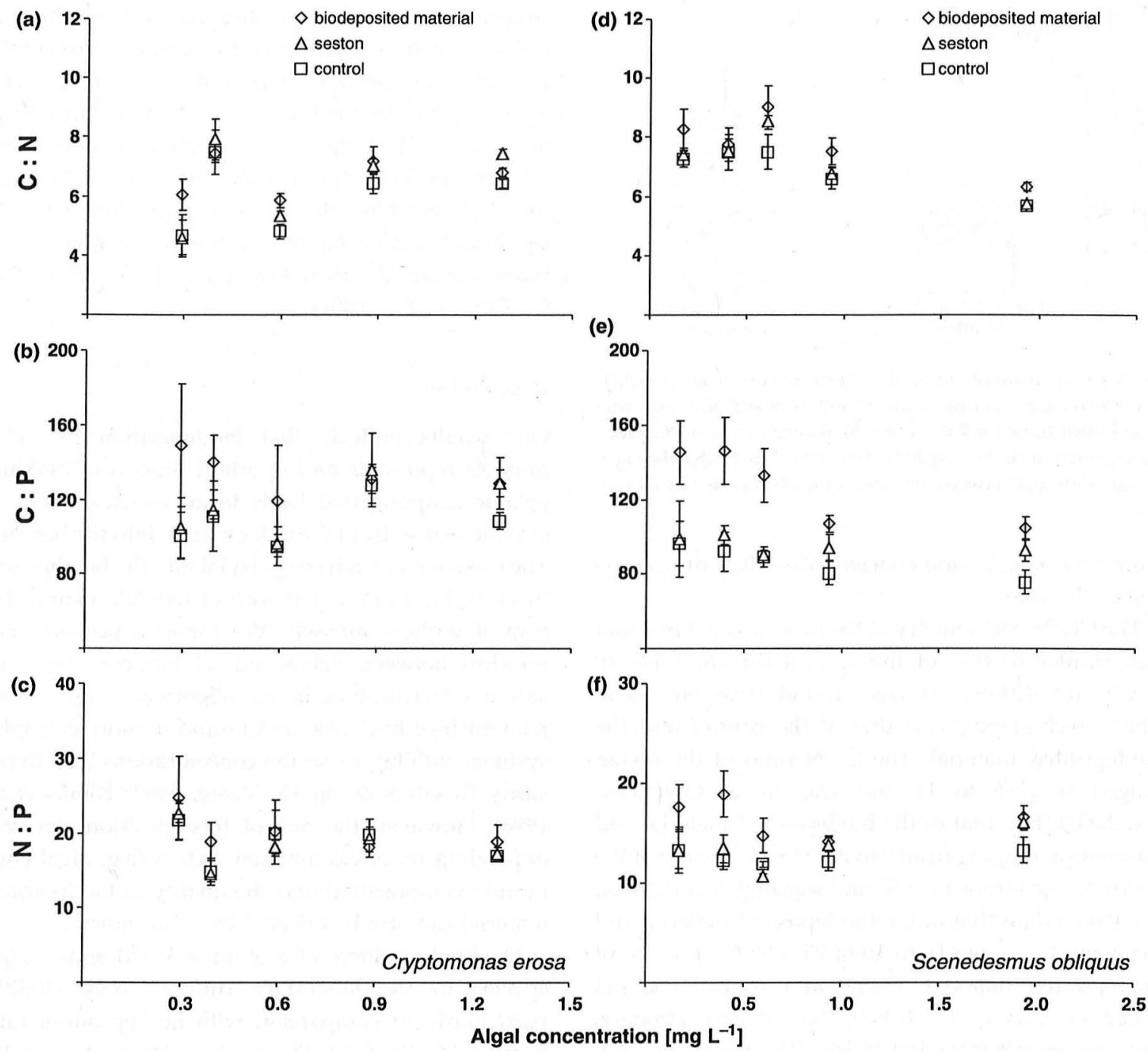

Fig. 2 Stochiometric composition in the experiment using Cryptomonas erosa and Scenedesmus obliquus as food. Elemental ratios for $(\mathrm{a} / \mathrm{b}) \mathrm{C}: \mathrm{N},(\mathrm{c} / \mathrm{d}) \mathrm{C}: \mathrm{P}$ and $(\mathrm{e} / \mathrm{f}) \mathrm{N}: \mathrm{P}$ of biodeposited material from Dreissena polymorpha, and of seston and the control are shown. The algal mass unit is mg ash-free dry mass.

community composition during spring was responsible for these relatively low biodeposition rates. To determine which of these two factors best accounts for the observations, we calculated different multiple linear regression models (Table 3) and used the Akaike Information Criterion (AIC) to find the model with the highest predictive power. The different algal community composition during spring explained as much as $81 \%$ of the observed variation in the biodeposition rates. The alternative model with water temperature as a covariate explained only $67 \%$. The best model, as indicated by AIC, is model
1.3 (Table 3), which assumes that the slope between biodeposition rate and seston concentration for spring samples is different from that of samples from other seasons.

Accordingly, two different significant regressions between seston concentration and biodeposition rate emerged: one for the spring samples and one for the samples from other seasons (Fig. 5, Table 1). The regression line for the algal spring bloom (MarchMay 2006 and 2007) was significantly lower than the regression for all other sampling dates (Table 3). During spring, the biodeposition rate increased less 


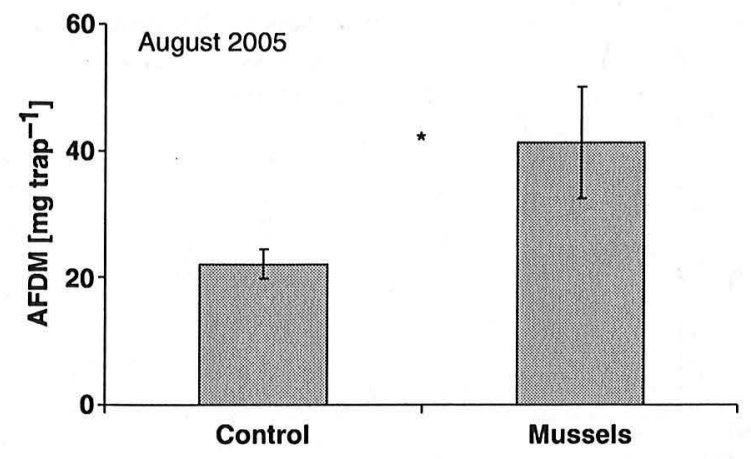

Fig. 3 Comparison of accumulated ash-free dry-mass (AFDM) in the two compartments 'control' and 'mussels' after exposure of sediment traps for 7 days $(n=5)$. Shown are the values for the experiment in August 2005. The asterisk indicates the significant different between the compartments revealed by a $t$-test.

with increasing seston concentration than during the rest of the year.

The CNP stoichiometry of the biodeposited material was similar to that of the control (Fig. 6, Table 2). Significant differences were found between seston CNP stoichiometry and that of the control and the biodeposited material. The $\mathrm{C}: \mathrm{N}$ ratio of the seston ranged from 6 to 12 and was lower (ANCOVA, $P<0.001)$ than that of the biodeposited material and the control, ranging from 9 to 28 . The $\mathrm{N}: \mathrm{P}$ ratio of the seston ranged from 15 to 50 and was higher (ANCOVA, $P<0.001$ ) than that of the biodeposited material and the control, ranging from 10 to 25 . The $\mathrm{C}: \mathrm{P}$ ratios of biodeposited material, seston and control did not differ (ANCOVA, $P=0.392$ ), but varied strongly, ranging overall from 100 to 500 . The trends in CNP stoichiometry for biodeposited material and the control to depend on seston concentration were similar (Fig. 6). This indicates that similar processes were operating in the treatment with and without zebra mussel, and that the effect of zebra mussels is not relevant for these effects. Both differed from the trend for CNP stoichiometry of seston, as shown by the significant compartment $\times$ seston interaction for all three measured ratios (ANCOVA: C:N, $P=0.009$; $\mathrm{C}: \mathrm{P} / \mathrm{N}: \mathrm{P}, \mathrm{P}<0.001)$.

\section{Discussion}

Our results indicate that biodeposition by zebra mussels represents an important process of benthicpelagic coupling that leads to an increased flow of organic matter from the pelagic zone into the benthos. The carbon flux from the pelagial into the benthos was twice as high in the presence of mussels than in the control without mussels. We found a positive relationship between zebra mussel biodeposition and seston concentration in an oligotrophic lake. Such relationships have also been found in more eutrophic systems with higher seston concentrations than in our study (Reeders \& Bij De Vaate, 1992; Klerks et al., 1996). However, the rate of biodeposition can vary depending on environmental factors (e.g. algal community composition) and the quality of biodeposited material can also be affected by zebra mussels.

The biodeposition rates of mussels fed on two algal species in the laboratory differed only slightly, particularly in comparison with biodeposition rates observed in the field. The biodeposition rate with the

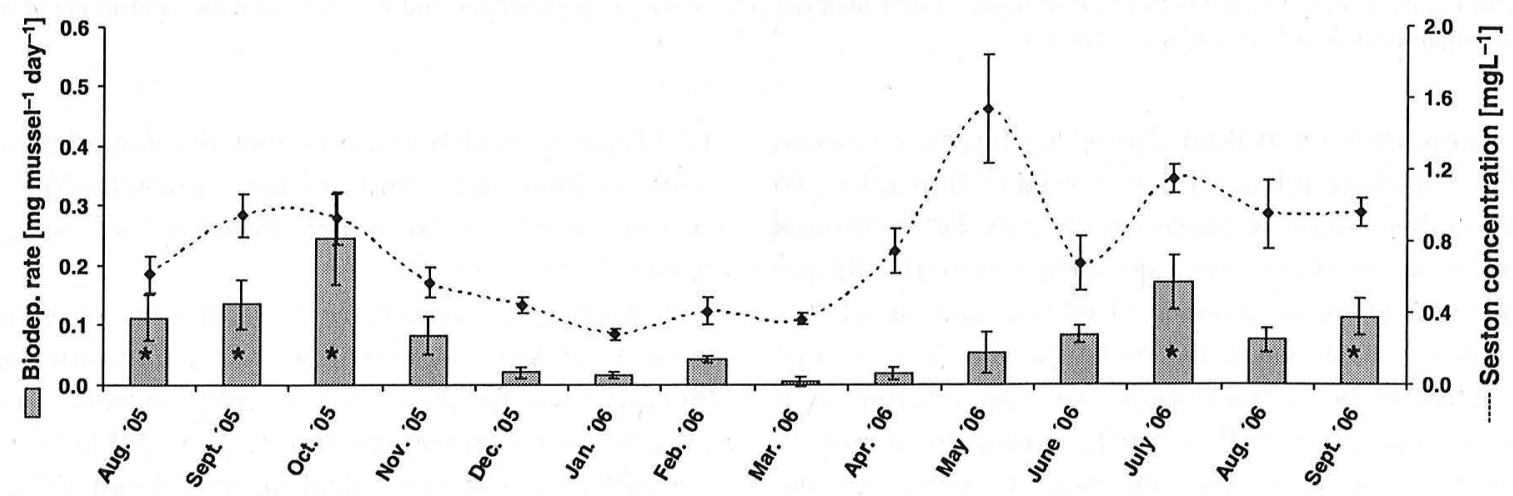

Fig. 4 Monthly biodeposition rate of Dreissena polymorpha and the seston concentration in Lake Constance from August 2005 to September 2006. The mass unit is mg ash-free dry mass. Asterisks indicate significantly higher rates than in December, January, March and April, detected by one-way ANOv A with a subsequent Tukey-HSD post-hoc test. 
Table 3 Multiple linear models with biodeposition rate as the dependent variable and different independent variables

\begin{tabular}{lllcrrr}
\hline Model & Independent variables & $R^{2}$ & $F$-value & d.f. & $P$-value* & AIC \\
\hline 1.1 & SC & 0.26 & 5.30 & 1,15 & 0.004 & -51.88 \\
1.2 & SC + SP & 0.69 & 15.89 & 2,14 & $<0.001$ & -64.88 \\
1.3 & SC + SP + SC $\times$ SP & 0.81 & 18.50 & 3,13 & $<0.001$ & -70.99 \\
2.1 & WT & 0.64 & 26.39 & 1,15 & $<0.001$ & -63.99 \\
2.2 & SC + WT & 0.65 & 13.06 & 2,14 & $<0.001$ & -62.64 \\
2.3 & SC + WT + SC $\times$ WT & 0.67 & 8.81 & 3,13 & 0.002 & -61.69 \\
\hline
\end{tabular}

SC, seston concentration; SP, spring; WT, water temperature. Note that SC and WT are continuous variables, whereas SP is a categorical variable (spring/not spring). Models were compared by applying the Akaike information criterion (AIC).

${ }^{*}$ A significant result.

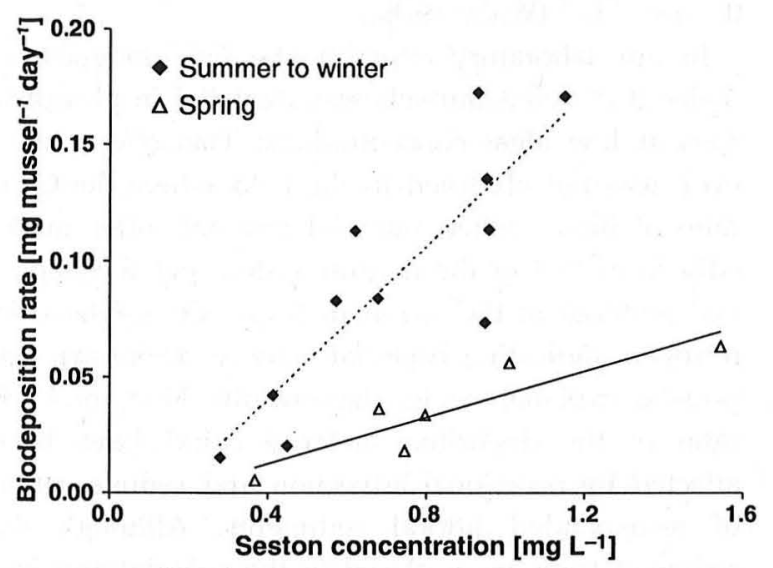

Fig. 5 Biodeposition rates and lake seston concentration in field experiments. The mass unit is $\mathrm{mg}$ ash-free dry mass. Lines represent linear regressions for the two seasons caused by different algae compositions; for statistics, see Tables $1 \& 3$.

algal cryptomonad C. erosa was slightly higher than that with the green alga S. obliquus. This contrasts with other studies where zebra mussels had higher clearance rates on cryptomonads than on green algae (Bastviken et al., 1998; Naddafi et al., 2007). A high preference for cryptomonads can be explained by the higher food quality of these algae, due to their $\mathrm{C}: \mathrm{N}: \mathrm{P}$ stoichiometry and high concentrations of long-chained polyunsaturated fatty acids (Vanderploeg, Liebig \& Gluck, 1996; Wacker \& Von Elert, 2004). However, the similar biodeposition rates when fed contrasting algae indicates that differences in food quality are of less importance for biodeposition. Both algal species are in the size range preferred by $D$. polymorpha (between 7 and $50 \mu \mathrm{m}$ ) and are therefore ingested at high rates, resulting in lower biodeposition rates (Ten Winkel \& Davids, 1982; Naddafi et al., 2007).
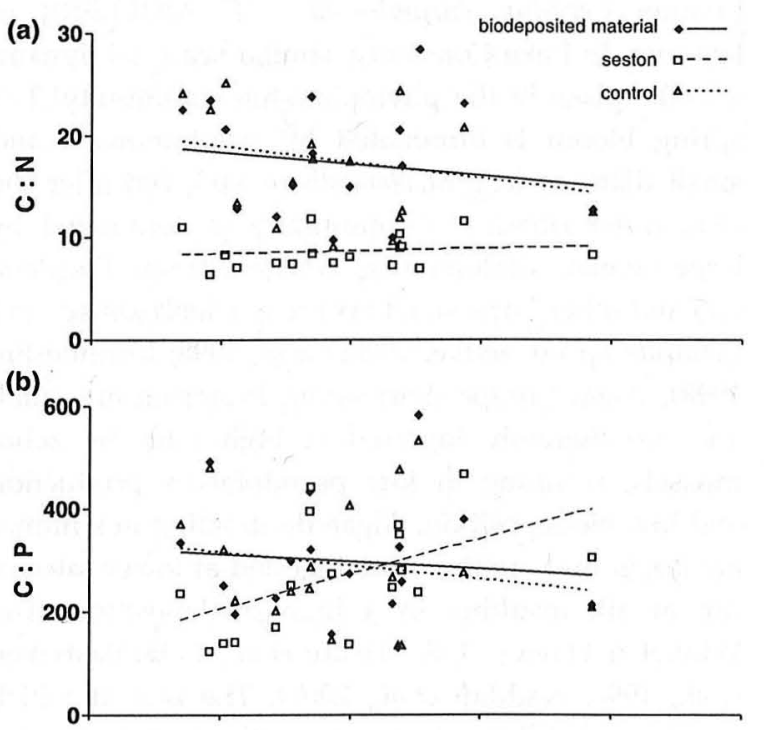

(c)

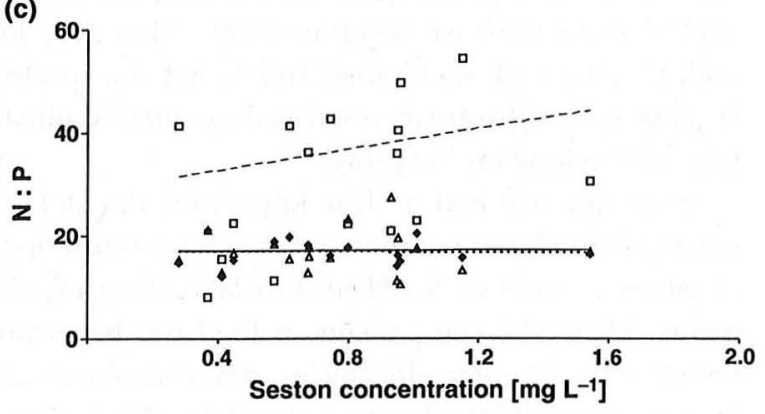

Fig. 6 Stochiometric composition in the field experiment at natural food conditions. Elemental ratios for (a) $C: N$, (b) $C: P$ and (c) N : P of biodeposited material from Dreissena polymorpha and of seston and the control are shown. The seston mass unit is $\mathrm{mg}$ ash-free dry mass.

Under natural conditions, the biodeposition rate of zebra mussels was also related to seston concentration, but seston concentration only explained a small proportion of biodeposition rate variation. A low 
dependence of zebra mussel biodeposition rate on seston concentration was also found by Reeders \& Bij De Vaate (1992). A second important factor was season, which had a higher predictive power than temperature. We observed a seasonal difference in biodeposition rate, with lower rates during the spring algal bloom compared to the rest of the year (Fig. 5). Similarly, Stanczykowska et al. (1975) found that zebra mussels had higher consumption and assimilation rates in spring than in summer, as a result of a seasonal shift in phytoplankton composition, with small diatoms in spring and large dinoflagellates [mainly Ceratium hirundinella (O.F. MÜLLER)] in summer. In Lake Constance, similar seasonal dynamics take place in the phytoplankton community. The spring bloom is dominated by cryptomonads and small diatoms (e.g. Stephanodiscus sp.), but after the clear-water phase the community is dominated by large pennate diatoms (e.g. Asterionella sp., Fragilaria sp.) and other large-sized taxa (e.g. Dinobryon sp. and Ceratium sp.) (Gaedke, 1998; Gege, 1998; Kümmerlin, 1998). Algal groups dominating in spring are small and are therefore ingested at high rates by zebra mussels, resulting in low pseudofaeces production and low biodeposition. Algae dominating in summer are larger and are therefore ingested at lower rates or not at all, resulting in a high biodeposition (Ten Winkel \& Davids, 1982; Heath et al., 1995; Bastviken et al., 1998; Naddafi et al., 2007). The rate at which zebra mussels deposit organic matter in spring agrees well with the rates we observed in the laboratory for both $C$. erosa and $S$. obliquus. This is not unexpected because both algae are as small as those that dominate lake phytoplankton in spring.

Zebra mussels had a clear impact on the stoichiometry of biodeposited material at low concentrations of either C. erosa or S. obliquus in laboratory experiments. Elemental components of food can be assimilated with different efficiencies and consumers are able to assimilate the limiting elements with a higher efficiency than carbon (Rothhaupt, 1995; Sterner \& Elser, 2002). Since phosphorous is the most limiting factor, especially in oligotrophic freshwater systems (Lampert \& Sommer, 1999), it would be reasonable for zebra mussels to assimilate phosphorous better than nitrogen, as was shown in our laboratory experiments. This differential phosphorus assimilation resulted in an increased $\mathrm{C}: \mathrm{P}$ ratio in the biodeposited material, potentially leading to further stoichiometric constraints for consumers of this biodeposited material. It is important to note that this altered $\mathrm{C}: \mathrm{P}$ ratio in the biodeposited material was only found when seston concentrations were low, when biodeposited material consists mostly of faeces. As seston content increases, the production of pseudofaeces becomes the dominant process for biodeposition and stoichiometric composition cannot change further. A significant depletion in phosphorous was only observed up to a concentration of $0.6 \mathrm{mg} \mathrm{AFDM} \mathrm{L} \mathrm{A}^{-1}$ (approximately $0.35 \mathrm{mg} \mathrm{C} \mathrm{L}^{-1}$ ). This concentration is slightly above the threshold of pseudofaeces production of $0.2 \mathrm{mg} \mathrm{C} \mathrm{L}^{-1}$ (Walz, 1978a).

In our laboratory experiments, the biodeposited material of zebra mussels was depleted in phosphorous at low algal concentrations. This effect, however, was not observed in the field where the $\mathrm{C}: \mathrm{P}$ ratio of biodeposited material did not differ markedly from that of the natural seston and the deposited material in the sediment traps was depleted in nitrogen, indicating bacterial activity. There are two possible explanations for these results. First, the C : P ratio of the deposited material could have been affected by occasional advection and sedimentation of resuspended littoral sediments. Although the sediment traps were placed in the pelagial and had no direct contact to the littoral, resuspended material from the littoral could have been transported to the experimental site during rough weather conditions and hence collected in the sediment traps. Secondly, the field experiments lasted 7 days, more than twice as long as the laboratory experiments. Microbial activity and microbial density in biodeposited material from zebra mussel can increase within a few days and accelerate its degradation (Izvekova \& Lvova-Katchanova, 1972; Roditi et al., 1997; Strayer et al., 1999). Simultaneously, an assemblage of ciliates, nematodes and rotifers could develop (Walz, 1978b). The shorter exposure of sediment traps in the field could potentially solve this problem in future field studies. Although we were not able to provide evidence for changing $\mathrm{C}: \mathrm{N}: \mathrm{P}$ stoichiometric composition of biodeposited material in the field, our laboratory experiments consistently showed such an effect at low food concentrations. We therefore hypothesise that this process has relevance also in situ, particularly in oligotrophic systems where stoichiometric constraints are most prominent (Hessen, 2006). 
Relevance for benthic communities in oligotrophic lakes

The in situ biodeposition rate of zebra mussels was highest in summer and lowest in winter, due to seasonal variation in seston concentration and composition. Consequently, the impact of zebra mussel biodeposition on the benthos is highest during summer, a time when benthic communities are most active. The contrast between seasons is amplified by winter losses of zebra mussels through consumption by overwintering diving ducks, which can prey heavily on zebra mussels. A reduction of more than $90 \%$ of zebra mussel biomass has been observed in Lake Constance during winter (Cleven \& Frenzel, 1993; Werner et al., 2005). In the following spring and summer, the population recovers by reproduction of the remaining young mussels and again reaches average densities of 10000 adult individuals $\mathrm{m}^{-2}$ with a mean size of $15 \mathrm{~mm}$ on littoral hard substrates (Mörtl, 2004; Werner et al., 2005). With a biodeposition rate of $0.15 \mathrm{mg} \mathrm{AFDM} \mathrm{mussel}{ }^{-1}$ day $^{-1}$ (cf. Fig. 4), a biomass of $1.5 \mathrm{~g} \mathrm{~m}^{-2}$ can be deposited by zebra mussels each day; this represents a significant benthic food source in a poorly productive system. For example, the amphipod Gammarus roeselii GERVAIS has a feeding rate of $0.3 \mathrm{mg}$ AFDM individual ${ }^{-1}$ day $^{-1}$ on the biodeposited material (Gergs \& Rothhaupt, $2008 b$ ). Hence, the material deposited just by zebra mussel filtration would be enough to sustain 5000 individuals $\mathrm{m}^{-2}$ of this $G$. roeselii in Lake Constance. In comparison, the abundance of $G$. roeselii in the littoral of Lake Constance is only up to approximately 500 individuals $\mathrm{m}^{-2}$ (Mörtl, 2004). Moreover, our estimate of potential daily biodeposition by $D$. polymorpha can account for the frequently observed year-round pattern of increase of organic matter in the benthos associated with the invasion of $D$. polymorpha (Stanczykowska et al., 1976; Klerks et al., 1996; Silver Botts et al., 1996; Ricciardi, Whoriskey \& Rasmussen, 1997). Furthermore, these results support the hypothesis that zebra mussels are responsible for the welldocumented increase in abundance of many benthic taxa (e.g. Stewart \& Haynes, 1994; Stewart et al., 1998; Mörtl \& Rothhaupt, 2003). The subsequent microbial colonisation of biodeposited material may additionally increase its nutritional value; chironomids show high growth rates on material deposited by $D$. polymorpha and assimilation rate increases with time since deposition (Izvekova \& Lvova-Katchanova, 1972).
These results indicate that material deposited by $D$. polymorpha substantially contributes to food availability for benthic communities and thereby increases overall benthic secondary production and macroinvertebrate density. These findings provide evidence for the existence of a Dreissena-biodeposition-based food web.

If we extrapolate the number of zebra mussels above the mouth area of the sediment trap used, the resulting mussel density in the benthic zone amounts to 1000 individuals $\mathrm{m}^{-2}$. In our field experiments, this mussel density led to sediment deposition rates twice as high as the control without mussels. The same enhancement of sediment deposition was found by Klerks et al. (1996), with a comparable mussel density of 1180 individuals $\mathrm{m}^{-2}$. Since the zebra mussel density in Lake Constance is 10-fold higher, the transfer of pelagic resources into the benthic zone is predominantly caused by the mussels.

While the importance of Dreissena biodeposition for benthic communities is very obvious, the empirical evidence for the importance to the pelagic habitat is questionable, especially in deep lakes. A study by Walz (1978b) estimated consumption by $D$. polymorpha to be only $2-3 \%$ of the pelagic primary production of Lake Constance. However, at that time, the density of $D$. polymorpha was much lower than today and mussel impact might now be higher; further studies are needed for verification. A completely different picture can, of course, be drawn for shallow lakes, where zebra mussels may have strong impacts on pelagic seston concentrations (Boegman et al., 2008).

\section{Acknowledgments}

We thank Jörg Deutzmann and Florian Kundinger for testing and establishing the experimental setups for the laboratory and field experiments. Martin Wolf contributed to the development of the sediment traps and manufactured them. We thank Christine Gebauer for analysing the $\mathrm{P}$ content and Petra Merkel for analysing the $\mathrm{C}$ and $\mathrm{N}$ contents. Karen A. Brune edited the English language of the manuscript. This work was supported by the DFG (German Research Foundation) within the collaborative research centre SFB 454 Littoral of Lake Constance and by the Zukunftskolleg of the University of Konstanz to KR. 


\section{References}

Bastviken D.T.E., Caraco N.F. \& Cole J.J. (1998) Experimental measurements of zebra mussel (Dreissena polymorpha) impacts on phytoplankton community composition. Freshwater Biology, 39, 375-386.

Boegman L., Loewen M.R., Hamblin P.F. \& Culver D.A. (2008) Vertical mixing and weak stratification over zebra mussel colonies in western Lake Erie. Limnology and Oceanography, 53, 1093-1110.

Cleven E.J. \& Frenzel P. (1993) Population dynamics and production of Dreissena polymorpha (Pallas) in River Seerhein, the outlet of Lake Constance (Obersee). Archiv für Hydrobiologie, 127, 395-407.

Gaedke U. (1998) Functional and taxonomic properties of the phytoplankton community of large and deep Lake Constance: Interannual variability and response to re-oligotrophication (1979-1993). Archiv für Hydrobiologie/Advances in Limnology, 53, 119141.

Gege P. (1998) Characterization of the phytoplankton in Lake Constance for classification by remote sensing. Archiv für Hydrobiologie/Advances in Limnology, 53, 179193.

Gergs R. \& Rothhaupt K.O. (2008a) Effects of zebra mussels on a native amphipod and the invasive Dikerogammarus villosus: the influence of biodeposition and structural complexity. Journal of the North American Benthological Society, 27, 541-548.

Gergs R. \& Rothhaupt K.O. (2008b) Feeding rates, assimilation efficiencies and growth of two amphipod species on biodeposited material from zebra mussels. Freshwater Biology, 53, 2494-2503.

González M.J. \& Burkart G.A. (2004) Effects of food type, habitat, and fish predation on the relative abundance of two amphipod species, Gammarus fasciatus and Echinogammarus ischnus. Journal of Great Lakes Research, 30, 100-113.

Greenberg A.E., Trussel R.R. \& Clesceri L.S. (1985) Standard Methods for the Examination of Water and Wastewater. APHA, Washington, DC.

Guillard R.R. (1975) Cultures of phytoplankton for feeding of marine invertebrates. In: Culture of Marine Invertebrate Animals (Eds W.L. Smith \& M.H. Chanley), pp. 26-60. Plenum Press, New York.

Heath R.T., Fahnenstiel G.L., Gardner W.S., Cavaletto J.F. \& Hwang S.J. (1995) Ecosytem-level effects of zebra mussel (Dreissena polymorpha): an enclosure experiment in Saginaw Bay, Lake Huron. Journal of Great Lakes Research, 21, 501-516.

Hessen D.O. (2006) Determinants of seston C : P-ratio in lakes. Freshwater Biology, 51, 1560-1569.
Holland R.E. (1993) Changes in the planktonic diatoms and water transparency in Hatchery Bay, Bass Island Area, Western Lake Erie since the establishment of the zebra mussel. Journal of Great Lakes Research, 19, 617624.

Internationale Gewässerschutzkommission Für Den Bodensee (2004) Der Bodensee Zustand-Fakten-Perspektiven. Internationale Gewässerschutzkommission für den Bodensee, Stuttgart, Germany. Available at: http://www.igkb.de.

Izvekova E.I. \& Lvova-Katchanova A.A. (1972) Sedimentation of suspended matter by Dreissena polymorpha Pallas and its subsequent utilization by chironomidaelarvae. Polnisches Archiv für Hydrobiologie, 19, 203-210.

Johnson J.B. \& Omland K.S. (2004) Model selection in ecology and evolution. Trends in Ecology and Evolution, 19, 101-108.

Jüttner F., Leonhardt J. \& Möhren S. (1983) Environmental factors affecting the formation of mesityloxide, dimethylallylic alcohol and other volatile compounds excreted by Anabaena cylindrica. Journal of General Microbiology, 129, 407-412.

Klerks P.L., Fraleigh P.C. \& Lawniczak J.E. (1996) Effects of zebra mussel (Dreissena polymorpha) on seston levels and sediment deposition in western Lake Erie. Canadian Journal of Fisheries and Aquatic Sciences, 53, 22842291.

Kümmerlin R.E. (1998) Taxonomic response of the Phytoplankton community of Upper Lake Constance (Bodensee-Obersee) to eutrophication and re-oligotrophication. Archiv für Hydrobiologie/Advances in Limnology, 53, 109-117.

Lampert W. \& Sommer U. (1999) Limnoecology. Georg Thieme Verlag, Stuttgart.

MacIsaac H.J. \& Rocha R. (1995) Effects of suspended clay on zebra mussel (Dreissena polymorpha) faeces and pseudofaeces production. Archiv für Hydrobiologie, 135, 53-64.

Mitchell J., Mills E.L., Idrisi N. \& Michener R. (1996) Stable isotopes of nitrogen and carbon in an aquatic food web recently invaded by Dreissena polymorpha (Pallas). Canadian Journal of Fisheries and Aquatic Sciences, 53, 1445-1450.

Mörtl M. (2004) Biotic Interactions in the Infralittoral of Lake Constance, PhD thesis. University of Konstanz, Konstanz.

Mörtl M. \& Rothhaupt K.O. (2003) Effects of adult Dreissena polymorpha on settling juveniles and associated macroinvertebrates. International Review of Hydrobiology, 88, 561-569.

Naddafi R., Pettersson K. \& Eklöv P. (2007) The effect of seasonal variation in selective feeding by zebra mus- 
sels (Dreissena polymorpha) on phytoplankton community composition. Freshwater Biology, 52, 823-842.

$\mathrm{R}$ Development Core Team (2006) $R$ : $A$ Language and Environment for Statistical Computing. R Foundation for Statistical Computing, Vienna, Austria.

Reeders H.H. \& Bij De Vaate A. (1992) Bioprocessing of polluted suspended matter from the water column by the zebra mussel (Dreissena polymorpha Pallas). Hydrobiologia, 239, 53-63.

Ricciardi A., Whoriskey F.G. \& Rasmussen J.B. (1997) The role of the zebra mussel (Dreissena polymorpha) in structuring macroinvertebrate communities on hard substrata. Canadian Journal of Fisheries and Aquatic Sciences, 54, 2596-2608.

Roditi H.A., Strayer D.L. \& Findlay S.E.G. (1997) Characteristics of zebra mussel (Dreissena polymorpha) biodeposits in a tidal freshwater estuary. Archiv für Hydrobiologie, 140, 207-219.

Rothhaupt K.O. (1995) Algal nutrient limitation affects rotifer growth rate but not ingestion rate. Limnology and Oceanography, 40, 1201-1208.

Siessegger B. (1969) Vorkommen und Verbreitung von "Dreissena polymorpha Pallas" im Bodensee. gwf wasser/abwasser, 110, 414-415.

Silver Botts P., Patterson B.A. \& Schloesser D.W. (1996) Zebra mussel effects on benthic invertebrates: physical or biotic? Journal of the North American Benthological Society, 15, 179-184.

Sprung M. \& Rose U. (1988) Influence of food size and food quantity on the feeding of the mussel Dreissena polymorpha. Oecologia, 77, 526-532.

Stanczykowska A., Lawacz W. \& Mattice J. (1975) Use of field measurements of consumption and assimilation in evaluation of the role of Dreissena polymorpha Pall. in a lake ecosystem. Polnisches Archiv für Hydrobiologie, 22, 509-520.

Stanczykowska A., Lawacz W., Mattice J. \& Lewandowski K. (1976) Bivalves as a factor effecting circulation of matter in Lake Mikolajskie (Poland). Limnologica, 10, 347-352.

Sterner R.W. \& Elser J.J. (2002) Ecological Stoichiometry: The Biology of Elements from Molecules to the Biosphere. Princeton University Press, Princeton.

Stewart T.W. \& Haynes J.M. (1994) Benthic macroinvertebrate communities of Southwestern Lake Ontario following invasion of Dreissena. Journal of Great Lakes Research, 20, 479-493.

Stewart T.W., Miner J.G. \& Lowe R.L. (1998) Quantifying mechanisms for zebra mussel effects on benthic macroinvertebrates: organic matter production and shell-generated habitat. Journal of the North American Benthological Society, 17, 81-94.

Strayer D.L., Caraco N.F., Cole J.J., Findlay S. \& Pace M.L. (1999) Transformation of freshwater ecosystems by bivalves. Bioscience, 49, 19-27.

Ten Winkel E.H. \& Davids C. (1982) Food selection by Dreissena polymorpha Pallas (Mollusca: Bivalvia). Freshwater Biology, 12, 553-558.

Underwood A.J. (2006) Experiments in Ecology: Their Logical Design and Interpretation Using Analysis of Variance. University Press, Cambridge.

Vanderploeg H.A., Liebig J.R. \& Gluck A.A. (1996) Evaluation of different phytoplankton for supporting development of zebra mussel larvae (Dreissena polymorpha): The importance of size and polyunsaturated fatty acid content. Journal of Great Lakes Research, 22, $36-45$.

Vanderploeg H.A., Liebig J.R., Carmichel W.W., Agy M.A., Johengen T.H., Fahnenstiel G.L. \& Nalepa T.F. (2001) Zebra mussel (Dreissena polymorpha) selective filtration promoted toxic Microcystis blooms in Saginaw Bay (Lake Huron) and Lake Erie. Canadian Journal of Fisheries and Aquatic Sciences, 58, 1208-1221.

Wacker A. \& Von Elert E. (2002) Strong influence of larval diet history on subsequent post-settlement growth in the freshwater mollusc Dreissena polymorpha. Proceedings of the Royal Society of London, Series B, 269, 2113-2119.

Wacker A. \& Von Elert E. (2003) Food quality controls reproduction of the zebra mussel (Dreissena polymorpha). Oecologia, 135, 332-338.

Wacker A. \& Von Elert E. (2004) Food quality controls egg quality of the zebra mussel Dreissena polymorpha: the role of fatty acids. Limnology and Oceanography, 49, 1794-1801.

Walz N. (1978a) The energy balance of the freshwater mussel Dreissena polymorpha PALLAS in laboratory experiments and in Lake Constance I. Pattern of activity, feeding and assimilation efficiency. Archiv für Hydrobiologie/Supplement, 55, 83-105.

Walz N. (1978b) The production and significance of the Dreissena population in the nutrient cycle in Lake Constance. Archiv für Hydrobiologie, 82, 482-499.

Werner S., Mörtl M., Bauer H.G. \& Rothhaupt K.O. (2005) Strong impact of wintering waterbirds on zebra mussel (Dreissena polymorpha) populations at Lake Constance, Germany. Freshwater Biology, 50, 1412-1426. 